Journal of English Language Teaching

UNNES

\title{
Pre-service EFL teachers' perception on technology-based formative assessment in their teaching practicum
}

\author{
Entika Fani Prastikawati ${ }^{\bowtie}$
}

Universitas PGRI Semarang, Indonesia

\begin{tabular}{l} 
Article Info \\
\hline Article History: \\
Received in 4 July \\
2021 \\
Approved in 27 July \\
2021 \\
Published in 28 July \\
2021 \\
\\
\hline Keywords: \\
technology-based \\
formative assessment; \\
pre-service EFL \\
teachers' perception; \\
teaching practicum.
\end{tabular}

\begin{abstract}
The spread of the pandemic COVID-19 has made many changes in educational policy such as the assessment in English teaching and learning process. The process and procedures in the assessment need to be adjusted from face-to-face assessment into blended and online assessments. Not only English teachers, pre-service EFL teachers are also required to be ready and adapt to the changes quickly. To adapt it, the integration of technology in the assessment process has been examined. However, the involvement of technology in the area of formative assessment remains underexplored, particularly in the teaching practicum conducted by pre-service EFL teachers. The present study is trying to fill the gaps by investigating pre-service EFL teachers' perception on technology-based formative assessment which is implemented in their teaching practicum. A total of 57 pre-service EFL teachers completed a Likertscale questionnaire. After fulfilling the questionnaires, there were 19 pre-service EFL teachers who agreed and volunteered to be in a semi-structured interview. The findings show that the involvement of technology in formative assessment is perceived positively by pre-service EFL teachers in their teaching practicum during the pandemic COVID-19. They confess that technology has played its practical role in helping them assess their students. Further, the implementation of technology-based formative assessments promotes the students' performance.
\end{abstract}

Sekaran, Gunungpati, Semarang, 50229

E-mail: entikafani@upgris.ac.id 


\section{INTRODUCTION}

The advancement of technology in education has been massively proliferated during the spread of the pandemic COVID-19 (Prastikawati, 2019; Prastikawati et al., 2020; Wiyaka \& Prastikawati, 2021). This is due to the changing shift in the teaching and learning process from face-to-face interaction into online interaction. This changing shift forces both teachers and students to have a transformative experiment in the process of teaching and learning (Abduh, 2021; Zhang et al., 2021). For that case, many educational institutions are obligated to apply the changes. The changes leave e-learning as the only option for teachers to interact with the students.

Adopting technology also occurs in assessment practices. The use of technology in assessment is considered a potential tool to assist the teachers to monitor and evaluate the students' learning (Brady et al., 2019; Deeley, 2018; Spector et al., 2016). On the other hand, some scholars mention that the complex process of adopting technology in the assessment process raises other problems. This complexity is influenced by the teacher's individual and technical factors that vary among them (Atmojo \& Nugroho, 2020; Starkey et al., 2021). According to Mimirinis (2019), the teacher's belief in how technology is utilized in assessment practices is also regarded as the crucial factor affecting the teacher's decision in using technology-based assessment.

Despite teacher's perception on technology-enhanced assessment, it is also important to see how the teachers perceive the assessment in the teaching and learning process. The fact shows that most teachers are familiar with summative assessment rather than formative assessment (Defianty et al., 2021). Meanwhile, formative assessment is highly needed by the teachers in gaining informative evidence on the students' learning. This kind of assessment can obtain information that is beneficial for the teachers to adjust their teaching instruction based on the students' needs. Further, formative assessment emphasizes feedback in bridging the gaps between the students' levels of competence and their learning goal (Vattøy, 2020). This constructive feedback in formative assessment also motivates the students to reach their learning goal (Zhu et al., 2020) as well as their autonomy in learning.

In English language teaching (ELT) context, integrating technology in formative assessment also has been widely accepted since the pandemic COVID-19. English teachers start improving their technological competence to support their ability in implementing formative assessment in their English teaching. The use of technology in formative assessment has been regarded as a help for the English teachers to reduce their workload (Beatty \& Gerace, 2009). Moreover, it also imparts the existed automatic feedback to the students' works.

Some studies have revealed that technology-based formative assessment is beneficial. Elmahdi et al. (2018) stated in their study that the involvement of technology in formative assessment practices improves both the teachers' and students' motivation in the process of teaching and learning. Further, the regular implementation of technology-enhanced formative assessment encourages the students to engage in their learning (Kent, 2019; Wiyaka \& Prastikawati, 2021). Another benefit of implementing technology-enhanced formative assessment is also mentioned by Hodgson \& Pang (2012). They reveal that technology in formative assessment creates great interest and curiosity for the students to demonstrate the given tasks. The students are eager to take part more in the impelementation of technology-enhanced formative assessments. Daly et al. (2010) also emphasize that online formative assessment leads to meaningful interactions between the teachers and the students. It implies that the use of online formative assessment has given the opportunities to enhance interactivity in the teaching and learning process.

Due to the importance of formative assessment as well as the technology enhancement in formative assessment practices, English teachers and pre-service EFL teachers should build their perception and conception of formative assessment well (Khodabakhshzadeh et al., 2018). Their assessment literacy must be developed to implement formative assessment on the right track. Furthermore, the previous studies mostly underline in-service EFL teachers' perspectives on the practice of technology-based formative assessment. Meanwhile, the discussion on how pre-service EFL teachers perceive technology in formative assessment practices during their teaching practicum is underexplored. For that reason, this current study is trying to fill the existing gaps by focusing on pre-service EFL teachers' perception on formative assessment and how they perceive the role of technology in formative assessment practices during their teaching practicum.

\section{METHOD}

This study employed a descriptive mixed-method design which connects the quantitative and qualitative phase by selecting the participants in the qualitative phase from those who responded to 
the questionnaire (quantitative phase). In the quantitative phase, I delivered a questionnaire for 57 pre-service EFL teachers. Meanwhile, in the qualitative phase, I conducted a semi-structured interview.

The participants of this study were 57 pre-service EFL teachers who have finished their teaching practicum (internship program). They were chosen as the sample by using purposive random sampling. In this case, 57 pre-service EFL teachers were those who conducted their teaching practicum in the senior high schools. This is based on the consideration that students in senior high school are more ready to use technology-based formative assessment in teaching and learning (Reddy et al., 2018).

In collecting the data, a Likert-scale questionnaire was given in the survey. This questionnaire was adopted and adapted from the previous research from Alotaibi (2018). This questionnaire was given in the google form since the COVID-19 pandemic spread. To support and gain more in-depth information from the questionnaire, the participants were invited to a semi-structured interview that was conducted in an online setting using the zoom application. There were 19 pre-service EFL (P1P19) teachers who agreed and volunteered to be interviewed. This semi-structured was fully recorded. In the interview process, the participants were allowed to use bahasa Indonesia or mixed it with English.

After collecting the first data from the questionnaire, I analyzed it using SPSS 21 in terms of mean (M) and standard deviation (SD). To measure the internal consistency and reliability, I employed Cronbach Alpha. Meanwhile, the data that was gained from the semi-structured interview was transcribed. The Indonesian transcripts were translated into English. Finally, it was sent back to the participant to check and get their confirmation and verification. To validate the data, I applied triangulation to the data that I got.

\section{FINDING AND DISCUSSION}

The finding and the discussion of this study focus on two main points; pre-service EFL teachers' perception on formative assessment and the role of technology enhancement in formative assessment practices.

\section{Pre-service EFL Teachers' Perception on Formative Assessment in the Teaching Practicum}

Capturing the perception of pre-service EFL teachers on formative assessment is the first agenda of this study since it is essential to know how pre-service EFL teachers value formative assessment in their English teaching practicum. According to table 1, pre-service EFL teachers perceive formative assessment positively $(\mathrm{M}=3.86 ; \mathrm{SD}=0.11)$. They believe that formative assessment has a substantial purpose to capture and monitor the students learning progress $(\mathrm{M}=3.78 ; \mathrm{SD}=0.99)$. This belief is in line with the conception that formative assessment can help the pre-service EFL teachers to check their students' understanding $(\mathrm{M}=3.91 ; \mathrm{SD}=0.95)$. This confirms how formative assessment is an integral part of English teaching and learning activity $(\mathrm{M}=3.84 ; \mathrm{SD}=0.94)$.

Table 1. Pre-service EFL Teachers' Perception on Formative Assessment

\begin{tabular}{lcc}
\hline \multicolumn{1}{c}{ Items } & $\mathrm{M}$ & $\mathrm{SD}$ \\
\hline $\begin{array}{l}\text { Formative assessment should be an integral part of teaching and } \\
\text { learning. }\end{array}$ & 3.84 & 0.94 \\
$\begin{array}{l}\text { Formative assessment helps the teachers to check the students' } \\
\text { understanding of the learning material that is learned. }\end{array}$ & 3.91 & 0.95 \\
$\begin{array}{l}\text { Formative assessment gives information to the teachers on the } \\
\text { students' learning progress during the teaching and learning } \\
\text { process. }\end{array}$ & 3.78 & 0.99 \\
$\begin{array}{l}\text { The regular formative assessment practices engage the student's } \\
\text { motivation in learning. }\end{array}$ & 3.89 & 1.03 \\
$\begin{array}{l}\text { The evidence from formative assessment practices can be used as a } \\
\text { teaching reflection for teachers to develop their teaching in the } \\
\text { future. }\end{array}$ & 3.98 & 0.95 \\
$\begin{array}{l}\text { Feedback in formative assessment helps the students to achieve } \\
\text { their learning goals. }\end{array}$ & 3.86 & 0.97 \\
$\begin{array}{l}\text { Peer-feedback among students in formative assessment is helpful } \\
\text { for students in evaluating a friend's work. }\end{array}$ & 3.61 & 0.90 \\
\hline
\end{tabular}




\begin{tabular}{|c|c|c|}
\hline $\begin{array}{l}\text { The teachers need more time to evaluate the students' works in } \\
\text { formative assessment }\end{array}$ & 3.87 & 1.07 \\
\hline $\begin{array}{l}\text { Formative assessment is assisting the teachers and students in } \\
\text { making a decision about how to move forward to reach their } \\
\text { goals. }\end{array}$ & 4.00 & 0.84 \\
\hline Overall & 3.86 & 0.11 \\
\hline
\end{tabular}

Responding to the questionnaire, how pre-service EFL teachers value formative assessment is also reflected in their interview. They consider formative assessment assists the students to engage in their English learning process by realizing their weaknesses and strength.

"I think formative assessment is crucial for us to do. It can be some activities such as giving the quiz, discussion, or even direct questions to students. These activities engage my students in their learning process and motivate them to learn more" (P4)

"I learn a lot in my teaching practicum especially about formative assessment. It is an important assessment to do by us as the teachers. Direct questioning was one of formative assessment I used to do in my teaching practicum. My students are motivated when I ask some questions on the materials that I explain."(P5)

"...I ever conducted online quizzes and direct questions for my students. I also asked my students to peer-assessment in my teaching practicum. They learned to share comments and opinions on their friends' works. To add, the activity can help my students to recognize their strength and weakness in their English learning" (P11)

Another finding is about feedback and its close relation with formative assessment. Based on table 1, pre-service EFL teachers believe that feedback in formative assessment is the help for students in achieving the goals of English learning $(\mathrm{M}=3.86 ; \mathrm{SD}=0.97)$. In the interview, they reveal that feedback from them is influential for students to make an English learning improvement.

"The feedback that I give to my students is really impactful. My students will revise their works based on what I commented. So, feedback in formative assessment is important" (P9)

"I know that feedback from me as the English teacher is good for my students' learning progress, but it takes time if I give feedback to all of my students. So, I let them do peer feedback. However, peerfeedback sometimes doesn't work since they feel awkward to comment negatively" (P13)

“...I prefer to use online feedback rather than direct feedback to my students' works. It helps me to save my time" (P15)

"Online feedback helped me so much in my formative assessment practices. It is not time-consuming". (P19)

Overall, pre-service EFL teachers have shown their efficacious perception towards formative assessment. They perceive formative assessment as a praiseworthy activity that is beneficial and impactful for the student's learning progress (Dalby \& Swan, 2019; Elmahdi et al., 2018). Meanwhile, formative assessment is more than just monitoring the students' learning progress in teaching and learning (Black \& Wiliam, 2010). The correct and regular formative assessment practices can obtain more information (Chong, 2018; Dalby \& Swan, 2019) that can be used by the teachers to adjust their teaching instructions, methods, and techniques which are suitable for the students' need and the curriculum demands (Hasim et al., 2018; Luthfiyyah et al., 2021).

Moreover, the evidence which is obtained from formative assessment can reveal the students' strengths and weaknesses, especially in English learning. This is then in line with the purpose of feedback in the formative assessment that is given by the teachers in supporting the students' improvement (Deeley, 2018). On the other hand, teachers also can take benefit from the evidence obtained from formative assessment by reflecting kinds of teaching instructions that are effective for the students (Owen, 2016). When the teachers find the teaching instructions are not suitable, they may reconstruct and choose another teaching instruction. Finally, the constructive and collaborative activities can impact the teaching and learning quality that is conducted by the teachers. Qualified teaching is also supposed to gain students' motivation in learning (Cauley \& McMillan, 2010; Prastikawati et al., 2020). This is essential to reach the main goal of learning. 


\section{The Roles of Technology in Formative Assessment Practices in the Teaching Practicum}

In the implementation of formative assessment in the teaching practicum, pre-service EFL teachers confess that technology has played an important role. Table 2 has shown pre-service EFL teachers' perception towards technology-enhanced formative assessment in their teaching practicum at schools $(\mathrm{M}=4.02 ; \mathrm{SD}=0.11)$. They have perceived that the multiple roles of technology in formative assessment practices help them to do the teachers' work efficiently and reduce their workloads $(\mathrm{M}=4.10 ; \mathrm{SD}=0.90)$. The use of technology also facilitates them to check the students' scores in a fast way $(\mathrm{M}=3.89$; $\mathrm{SD}=1.04)$, so the feedback for the students can also follow it quickly $(\mathrm{M}=3.91$; $\mathrm{SD}=0.96)$.

"...It is a help for me to involve technology in my formative assessment when I have a teaching practicum. Moreover, the online learning setting supports the technology advancement in formative assessment practices that I regularly do in my English teaching"(P5)

"It is fun to have ICT in my formative assessment practices especially in my teaching practicum. I can save my time and reduce my overload work that I must do"(P8)

"I like using technology in the formative assessment such as online quizzes in Kahoot and Quizziz. The feedback is quick for my students and it saves my time"(P19)

Pre-service EFL teachers also reveal that the involvement of technology in formative assessment practices brings a new atmosphere of learning which is suitable for today's education needs. The use of online quiz platforms such as Kahoot, Quizziz, and Socrative apps present a challenging and exciting learning environment. The touch of online platforms leads the students to be more competitive and engaged in learning. automatically, their learning motivation is increased $(\mathrm{M}=4.14 ; \mathrm{SD}=0.91)$. It is a good condition for the students to play their best roles in making an effort in their study.

Table 2. The Roles of Technology in Formative Assessment Practices in the Teaching Practicum

\begin{tabular}{lcc}
\hline \multicolumn{1}{c}{ Items } & M & SD \\
\hline $\begin{array}{l}\text { Using technology in formative assessment practices helps the teachers } \\
\text { to reduce their workload. }\end{array}$ & 4.10 & 0.90 \\
$\begin{array}{l}\text { Using technology in formative assessment can assist the teachers to } \\
\text { easily monitor the students' learning progress. } \\
\text { The technology-advanced formative assessment facilitates the students } \\
\text { to study independently and collaboratively. }\end{array}$ & 4.07 & 0.88 \\
$\begin{array}{l}\text { The technology-advanced formative assessment facilitates the students } \\
\text { to get quick feedback }\end{array}$ & 3.91 & 0.85 \\
$\begin{array}{l}\text { The technology-advanced formative assessment facilitates the students } \\
\text { to check their score as quickly as possible }\end{array}$ & 3.89 & 1,04 \\
$\begin{array}{l}\text { The use of technology-advanced formative assessment in online } \\
\text { quizzes offers an entertaining task environment }\end{array}$ & 3.93 & 1.06 \\
$\begin{array}{l}\text { The use of technology-advanced formative assessment maintain } \\
\text { motivates the students to improve their learning performance. }\end{array}$ & 4.14 & 0.91 \\
\hline Overall & $\mathbf{4 . 0 2}$ & $\mathbf{0 . 1 1}$ \\
\hline
\end{tabular}

According to pre-service EFL teachers' responses in table 2, another role of technology in formative assessment is as a fast monitor of the student's learning progress $(\mathrm{M}=4.07 ; \mathrm{SD}=0.88)$. The teachers' role in monitoring the students' learning is a must in the teaching and learning process, so it is clear that technology has helped the teachers to do it efficiently. The advancement of technology in the implementation of formative assessment practices leads to the efficiency of the works that preservice EFL teachers need to do in their teaching practicum. Moreover, the principle of practicality in the assessment process is also mentioned by pre-service EFL teachers when using technology in the implementation of formative assessment in their online English teaching. 
“...I ever implemented Plickers and it was helpful for me to monitor the student's learning progress quickly. For me, Plickers could play well in formative assessment practice"(P14)

"Kahoot is one of the technology-based formative assessment that I used in teaching practicum. It is like a helper for me to check my students' learning progress whether they have comprehended and understood what I have explained before or not."(P16)

"..Kahoot and Quizziz application is so practical for me. Those applications are so simple to be implemented as online formative assessment practices in the classroom. Both online and face to face classroom setting can use them anytime."(P7)

Furthermore, technology-enhanced formative assessment facilitates the students to learn both individually and collaboratively $(\mathrm{M}=4.14 ; \mathrm{SD}=0.85)$. Pre-service $\mathrm{EFL}$ teachers reveal that collaborative learning can be realized in online formative assessment practices such as commenting, editing, and revising the works in peer or group. The students were set in a group by using zoom's break-out room provided by the teacher to works together.

"The use of technology in my formative assessment practices can realize the concept of collaborative learning. I let my students work together and comment on the work each other...."(P7)

"Technology-based formative assessment has brought a new and challenging learning environtment that is related to today's demand."(P10)

“...I let my students to write in a small group using Google Docs. They work together in drafting, editing, revising their writing"(P11)

"...collaborative learning is realized easily by the help of techmology-based formative assessment. The students are in the different places but they still can work together using an online application such as Google Docs. They are encouraged more in improving their learning quality, especially in writing process" (P15)

As it has been explained in the findings that pre-service EFL teachers value the technology enhancement as an effective tool in implementing formative assessment in their teaching practicum. The multiple roles of technology in formative assessment have assisted the teachers in reducing the workloads, monitoring the students' learning progress, presenting a challenging learning environment, motivating the students in individual and collaborative learning, and engaging both teachers and students in the teaching and learning process. Those multiple roles of technology in formative assessment are considered efficacious values for pre-service EFL teachers in conducting their teaching practicum. Furthermore, the advancement of technology in formative assessment practices also impacts on the pre-service EFL teachers' teaching quality. The quick way resulted from some online application of formative assessment assists pre-service EFL teachers to make an adjustment in their teaching technique or media so that the quality of teaching is improved. In short, the role of technology in formative assessment cannot be neglected to present the qualified teaching for students.

The first role of technology in formative assessment is reducing the teachers' workloads. As it is mentioned by Prastikawati et al. (2020), presenting qualified teaching and learning process is important to reach the main goal of learning. In this case, the teachers' works become complex such as providing feedback (Gikandi et al., 2011) for students relating their submitted and unsubmitted works. Pre-service EFL teachers have mentioned that they need more time to check and give feedback to the students. Point to that, the use of technology in formative assessment practices reduces those time-consuming activities (Brady et al., 2019; Mahbub, 2020). The use of online quizzes has placed technology-based formative assessment in the current need of learning such as instant feedback for the students. It means that technology-based formative assessment presents fast transparency of the students' work (Spector et al., 2016; Zainuddin et al., 2020). The fast transparency of the students' work in technology-enhanced formative assessment is also beneficial for the teachers to monitor the student' learning progress. By knowing the improvement of the students' work, the teachers can adjust their teaching instruction. This is in line with the second role of technology in formative assessment perceived by pre-service is monitoring the students' learning progress quickly. 
The second role of technology in formative assessment is regarded as an efficient tool to monitor the students' work in a fast and valid way. Technology has presented its benefit in term of the speed in monitoring the learning progress in everytime the material has been delivered. Zainuddin et al. (2020) mention that it is crucial for the teachers to check the students' understanding on the materials that has been delivered so that the teachers can decide to continue or not. This is an impactful process that should be well-considered by the English teachers to improve the learning quality. As one of the principles of formative assessment is to clearly monitor each learning process acquired by the students, so the teacher is the main actor to realize it. The information that is derived from formative assessment result is beneficial for the teachers to adapt and adjust the learning instructions pthat are presented in the class. Further, this result also effects for the students to improve their learning strategies. Here, the technology becomes the assistant of the teachers in completing their role in checking the students' understanding so that the result of formative assessment can be accessed as soon as possible. This is one of technology speciality that may not be found in non-technology based formative assessment.

Another role of technology in formative assessment is leading the students to both individual and collaborative learning. In an individual learning, the student can realize their weakness and strength from the individual feedback given by the teachers. The more feedback in online formative assessment practices, the better improvement of a student will reach (Burner, 2016; Tosuncuoglu, 2018). Meanwhile, the use of technology in formative assessment also highlights the concept of collaborative learning. One of the examples is collaborative writing in a small group using Google Docs. Using this kind of technology-enhanced formative assessment can write, edit, and revise with their friends in a small group. Meanwhile, the teacher also can monitor the students' writing activities in this kind of collaborative activity. Furthermore, this kind of technology-enhanced formative assessment motivate the students to share and respect what the other friends comment into. It creates a new learning environment for students especially when it relates to do some tasks. The challenging environment in an online formative assessment may stimulates them in an active task participant. An active and interactive student will lead to the successful teaching and learning that ends to qualified learning.

Finally, the realization of technology in formative assessment practices can be explored maximumly in the teaching practicum if pre-service EFL teachers improve their technological competence. This competence is a must in today's teaching and learning requirement since the online teaching and learning still exists in the pandemic era.

\section{CONCLUSION}

The current study has revealed that the involvement of technology in formative assessment practices has been perceived positively by pre-service EFL teachers in conducting their teaching practicum. They have mentioned that the multiple roles of technology in formative assessment practices help them in achieving the qualified teaching and learning that is beneficial for the students' learning achievement. Furthermore, the technology involvement also plays an essential role for the improvement of pre-service EFL teachers' technological competence in which it is considered as a must for today's teaching competence (Atmojo \& Nugroho, 2020). However, pre-service EFL teachers need more disclosure as well as exposure to the assessment knowledge and purposes. Furthermore, pre-service EFL teachers also need to improve their competence on technology uses to support the formative assessment practices in their teaching practicum. Since this study involves limited participants, it is essential for the further research to crry out a larger sample. Moreover, the impact of technology-based formative assessment on certain language skills competences needs to be explored including the numerous factors influencing pre-service EFL teachers in applying of technology-based formative assessment.

\section{REFERENCES.}

Abduh, M. Y. M. (2021). Full-time online assessment during COVID -19 lockdown: EFL teachers' perceptions. Asian EFL Journal, 28(11), 26-46.

Alotaibi, K. A. (2018). Teachers' perceptions on factors influence adoption of formative assessment. Journal of Education and Learning, 8(1), 74. https://doi.org/10.5539/jel.v8n1p74

Atmojo, A. E. P., \& Nugroho, A. (2020). EFL classes must go online! Teaching activities and challenges during COVID-19 pandemic in Indonesia. Register Journal, 13(1), 49-76. 
https://doi.org/10.18326/rgt.v13i1.49-76

Bahati, B. (2019). Technology-enhanced formative assessement in higher education. In Handbook of Formative Assessment in the Disciplines (Issue 19).

Beatty, I. D., \& Gerace, W. J. (2009). Technology-enhanced formative assessment: A research-based pedagogy for teaching science with classroom response technology. Journal of Science Education and Technology, 18(2), 146-162. https://doi.org/10.1007/s10956-008-9140-4

Black, P., \& Wiliam, D. (2010). Inside the black box: Raising standards through classroom assessment. Phi Delta Kappan, 92(1), 81-90. https://doi.org/10.1177/003172171009200119

Brady, M., Devitt, A., \& Kiersey, R. A. (2019). Academic staff perspectives on technology for assessment (TfA) in higher education: A systematic literature review. British Journal of Educational Technology, 50(6), 3080-3098. https://doi.org/10.1111/bjet.12742

Burner, T. (2016). Formative assessment of writing in English as a foreign language. Scandinavian Journal of Educational Research, 60(6), 626-648. https://doi.org/10.1080/00313831.2015.1066430

Cauley, K. M., \& McMillan, J. H. (2010). Formative assessment techniques to support student motivation and achievement. The Clearing House: A Journal of Educational Strategies, Issues and Ideas, 83(1), 1-6. https://doi.org/10.1080/00098650903267784

Chong, S. W. (2018). Three paradigms of classroom assessment: Implications for written feedback research. Language Assessment Quarterly, 15(4), 330-347. https://doi.org/10.1080/15434303.2017.1405423

Dalby, D., \& Swan, M. (2019). Using digital technology to enhance formative assessment in Mathematics classrooms. British Journal of Educational Technology, 50(2), 832-845. https://doi.org/10.1111/bjet.12606

Daly, C., Pachler, N., Mor, Y., \& Mellar, H. (2010). Exploring formative e-assessment: Using case stories and design patterns. Assessment and Evaluation in Higher Education, 35(5), 619-636. https://doi.org/10.1080/02602931003650052

Deeley, S. J. (2018). Using technology to facilitate effective assessment for learning and feedback in higher education. Assessment and Evaluation in Higher Education, 43(3), 439-448. https://doi.org/10.1080/02602938.2017.1356906

Defianty, M., Hidayat, D., Kultsum, U., Sufyan, A., Subchi, I., \& Sururin, S. (2021). Reframing formative assessment practices in emergency remote teaching context of English language teaching in higher education institutions Indonesia. https://doi.org/10.4108/eai.20-10-2020.2305143

Elmahdi, I., Al-Hattami, A., \& Fawzi, H. (2018). Using technology for formative assessment to improve students' learning. TOJET: The Turkish Online Journal of Educational Technology, 17(2), $182-188$.

Elumalai, K. V., Sankar, J. P., R, K., John Ann, J., Menon, N., Alqahtani, M. S. M., \& Abumelha, M. A. (2020). Factors affecting the quality of e-learning during the COVID-19 pandemic from the perspective of higher education students. Journal of Information Technology Education: Research, 19(1), 731-753. https://www.learntechlib.org/p/218286

Gikandi, J. W., Morrow, D., \& Davis, N. E. (2011). Online formative assessment in higher education: A review of the literature. Computers and Education, 57(4), 2333-2351. https://doi.org/10.1016/j.compedu.2011.06.004

Hasim, Z., Di, S., \& Barnard, R. (2018). Eliciting teachers' understanding and their reported practices on school-based formative assessment: Methodological challenges. Indonesian Journal of Applied Linguistics, 8(1), 158-166. https://doi.org/10.17509/ijal.v8i1.11476

Hodgson, P., \& Pang, M. Y. C. (2012). Effective formative e-assessment of student learning: A study on a statistics course. Assessment and Evaluation in Higher Education, 37(2), 215-225. https://doi.org/10.1080/02602938.2010.523818

Kent, D. (2019). Plickers and the pedagogical practicality of fast formative assessment. Teaching English with Technology, 19(3), 90-104. 
Khodabakhshzadeh, H., Kafi, Z., \& Hosseinnia, M. (2018). Investigating EFL teachers' conceptions and literacy of formative assessment: Constructing and validating an inventory. International Journal of Instruction, 11(1), 139-152. https://doi.org/10.12973/iji.2018.11110a

Luthfiyyah, R., Aisyah, A., \& Sulistyo, G. H. (2021). Technology-enhanced formative assessment in higher education: A voice from Indonesian EFL teachers. EduLite: Journal of English Education, Literature and Culture, 6(1), 42. https://doi.org/10.30659/e.6.1.42-54

Mahbub, M. A. (2020). Learning English mediated by Kahoot: Insights from the Indonesian EFL instructors. Journal on English as a Foreign Language, 10(2), 246-267. https://doi.org/10.23971/jefl.v10i2.1917

Mimirinis, M. (2019). Qualitative differences in academics' conceptions of e- assessment. Assessment \& Evaluation in Higher Education, 44(2), 233-248. https://doi.org/https://doi.org/10.1080/02602938.2018.1493087.

Owen, L. (2016). The impact of feedback as formative assessment on student performance. International Journal of Teaching and Learning in Higher Education, 28(2), 168-175.

Prastikawati, E. F. (2019). Dyned programme as Computer Assisted Language Learning (CALL) for university students: A perception and its impact. International Journal of Emerging Technologies in Learning, 14(13), 4-20. https://doi.org/10.3991/ijet.v14i13.10448

Prastikawati, E. F., Wiyaka, W., \& Adi, A. P. K. (2020). Online backchannel as a formative assessment in improving writing skills. Journal on English as a Foreign Language, 10(2), 359-384. https://doi.org/10.23971/jefl.v10i2.2044

Reddy, E., Sharma, B., Reddy, P., \& Dakuidreketi, M. (2018). Mobile learning readiness and ICT competency: A case study of senior secondary school students in the pacific islands. Proceedings 2017 4th Asia-Pacific World Congress on Computer Science and Engineering, APWC on CSE 2017, 137143. https://doi.org/10.1109/APWConCSE.2017.00031

Spector, J. M., Ifenthaler, D., Sampson, D., Yang, L. J., Mukama, E., Warusavitarana, A., Dona, K. L., Eichhorn, K., Fluck, A., Huang, R., Bridges, S., Lu, J., Ren, Y., Gui, X., Deneen, C. C., Diego, J. S., \& Gibson, D. C. (2016). Technology enhanced formative assessment for 21st century learning. Educational Technology and Society, 19(3), 58-71.

Starkey, L., Shonfeld, M., Prestridge, S., \& Cervera, M. G. (2021). Special issue: COVID-19 and the role of technology and pedagogy on school education during a pandemic. Technology, Pedagogy and Education, 30(1), 1-5. https://doi.org/10.1080/1475939X.2021.1866838

Tosuncuoglu, I. (2018). Importance of assessment in ELT. Journal of Education and Training Studies, 6(9), 163. https://doi.org/10.11114/jets.v6i9.3443

Vattøy, K. D. (2020). Teachers' beliefs about feedback practice as related to student self-regulation, self-efficacy, and language skills in teaching English as a foreign language. Studies in Educational Evaluation, 64(November 2019), 100828. https://doi.org/10.1016/j.stueduc.2019.100828

Wiyaka, \& Prastikawati, E. F. (2021). Plickers as an online formative assessment to improve secondary school students' English learning. The 3rd International Education and Social Science Research (ICESRE 2021), 302, 1-16.

Zainuddin, Z., Shujahat, M., Haruna, H., \& Chu, S. K. W. (2020). The role of gamified e-quizzes on student learning and engagement: An interactive gamification solution for a formative assessment system. Computers and Education, 145, 103729. https://doi.org/10.1016/j.compedu.2019.103729

Zhang, C., Yan, X., \& Wang, J. (2021). EFL teachers' online assessment practices during the COVID19 pandemic: Changes and mediating factors. The Asia-Pacific Education Researcher. https://doi.org/10.1007/s40299-021-00589-3

Zhu, M., Liu, O. L., \& Lee, H. S. (2020). The effect of automated feedback on revision behavior and learning gains in formative assessment of scientific argument writing. Computers and Education, 143(September 2018), 103668. https://doi.org/10.1016/j.compedu.2019.103668 